\title{
Neutral Bystander, Intrusive Micromanager, or Useful Catalyst?: The Role of Congress in Effecting Change Within the Forest Service
}

\section{Elise S. Jones and Will Callaway}

\begin{abstract}
An analysis of Forest Service-related legislative activity found that increasingly Congress is becoming involved in agency activities and decisionmaking. Congress's growing scrutiny and management of the Forest Service is indicated by rising trends in requests for agency testimony at congressional hearings, in the number of Forest Service-related bills and amendments introduced in Congress, and in the amount of Forest Servicerelated legislation enacted. Anecdotal evidence of direct political pressure imposed upon agency personnel by congressional members also indicates that much congressional influence occurs outside of these legislative activities. An examination of activities such as these and directives attached to annual appropriation bills also shows that not all congressional actions are productive in fostering positive agency change. The results of this study indicate the likelihood that Congress has been playing a major role in instigating change within the agency.
\end{abstract}

Congress has had a role in the management of America's National Forests for more than 100 years, beginning with its enactment of the 1891 Forest Reserve Act, which gave the President the authority to set aside forested lands as preserves, and the 1905 law that created the Forest Service (USFS) to oversee these lands (Dana \& Fairfax, 1980). Since then, Congress has had the potential to affect greatly how the agency operates and manages the National Forests. Congressional involvement in Forest Service activities can take a variety of forms. It can impose new statutory obligations on the agency through legislation, set the agency's budget allocations via the appropriations process, attach directives to annual funding bills or in report language, hold hearings on Forest Service programs, set timber harvest targets, initiate investigations of agency activities, question and negotiate agreements with agency representatives during congressional hearings, and directly lobby or pressure Forest Service personnel (Congressional Quarterly, 1991b). Given the diversity of views and geographic locations represented within Congress, federal legislators' input into agency programs and decisionmaking can push and pull the Forest Service in a variety of ways, from greater emphasis on traditional commodity extraction from the National Forests to increased protection of the forest environment. Additionally, while congressional involvement in Forest Service activities is often resented as inappropriate "micromanagement," at other times congressional attention is welcomed and even invited by the agency (Dana \& Fairfax, 1980). Such congressional involvement also can provide needed oversight of Forest Service management activities.

The context within which the Forest Service has managed the National Forests has changed dramatically over the past 88 years, in particular with regard to our scientific understanding of forest management, the level of and desire for public involvement in forest management decisions, and public preferences for National Forest uses (Tipple \& Wellmann, 1991; Kennedy, 1988). There is an ongoing debate over whether the Forest Service has been evolving to reflect the changing public climate in which it must manage the National Forests and, if so, what the source of that change is (see, for example, Jones \& Mohai, 1995; Mohai, 1995; Mohai \& Jakes, in 
press). Several scholars have documented a shift within the agency away from its traditional emphasis on timber production, as described by Dana and Fairfax (1980) and Twight (1983), and toward a greater focus on ecosystem management and noncommodity uses of the National Forests. As evidence, they point to observed changes in resource management activities (Farnham \& Mohai, 1995; Farnham, Taylor, \& Callaway, 1995), shifts in agency budget requests and appropriations (Farnham, 1995), perceptions held by interest groups involved in forest planning (Jones \& Mohai, 1995), and surveyed changes in the values and attitudes of Forest Service personnel (Mohai, Stillman, Jakes, \& Liggett, 1994; Kennedy, Krannich, Quigley, \& Cramer, 1993; Brown \& Harris, 1992a, 1992b; McCarthy, Sabatier, \& Loomis, 1991).

Several potential sources have been suggested and analyzed as possible catalysts for this observed agency change. These include internal forces such as shifts in the gender, racial, and professional diversity of the USFS workforce (Thomas \& Mohai, 1995; Mohai, Stillman, Jakes, \& Liggett, 1994; Brown \& Harris, 1993; Kennedy, 1991; McCarthy, Sabatier, \& Loomis, 1991), as well as external forces such as the courts and outside interest groups (Jones \& Taylor, 1995; Tipple \& Wellmann, 1991; Ackerman, 1990; Kennedy, 1988; Wenner, 1982; Culhane, 1981). In particular, several scholars have hypothesized that Congress and the federal laws it has enacted have had a significant impact on the Forest Service (Tipple \& Wellmann, 1991; Ackerman, 1990; Kennedy, 1988; Wenner, 1982). To date, however, no studies have provided data to support these arguments. Specifically, there has been no attempt to quantify congressional involvement in agency management activities or to examine trends in this involvement over time.

This article attempts to help fill these gaps by examining the potential role that Congress has played in influencing change in the Forest Service since the passage of the National Forest Management Act in 1976 (NFMA). We begin with a brief description of major environmental legislation affecting the Forest Service, and then provide a sampling of qualitative evidence of congressional influence via annual appropriation bill directives and direct pressure on agency leaders and staff. This is followed by a quantitative analysis of trends in agency participation in congressional hearings and in the number of Forest Service-related bills and amendments introduced and passed by Congress each year. Our hypothesis is that if Congress is the catalyst for any of the recently observed change within the agency, we should find an increase in congressional activity related to the Forest Service to correspond with this change. A positive correlation alone would not provide conclusive proof that Congress is a source of recent agency change, but it would indicate a likelihood that Congress has played a role in influencing the Forest Service.

\section{Background}

Three primary bodies in each chamber of Congress oversee the activities of the Forest Service (Congressional Quarterly, 1988). The committees in the House of Representatives consist of Agriculture, Appropriations, and Resources (formerly Natural Resources and, prior to that, Interior and Insular Affairs). Their Senate counterparts are Agriculture, Nutrition and Forestry; Appropriations; and Energy and Natural Resources. The four non-appropriations committees have jurisdiction over all authorizing legislation, which controls the statutory obligations of the Forest Service (Congressional Quarterly, 1991a). The Appropriations Committees dictate the agency's spending for the upcoming fiscal year via the appropriation levels set in the annual Department of Interior and Related Agencies Appropriations bill (Congressional 
Quarterly, 1988). Much of the work of these committees occurs at the subcommittee level, and other committees also have jurisdiction over certain issues involving the agency (Congressional Quarterly, 1991b), such as the protection of threatened and endangered species, which is overseen in the Senate by the Environment and Public Works Committee. In addition, amendments affecting the Forest Service may be offered to bills by members on the House and Senate floors; this practice is a common means to bypass the authorizing committees, especially with appropriations bills (Congressional Quarterly, 1991a).

\section{Major Legislation Affecting the USFS}

As noted by Terry West, Director of the Forest Service's History Unit, laws passed by Congress during the climax of the environmental movement in the 1960s and 1970s are directing much of the activities of the agency today (West, 1992). Among the many environmental laws enacted during this period are the 1960 Multiple-Use Sustained Yield Act, the 1964 Wilderness Act, the 1968 Wild and Scenic Rivers Act, the 1969 National Environmental Policy Act (NEPA), the 1973 Endangered Species Act, the 1974 Resources Planning Act (RPA), and the 1976 National Forest Management Act. These pieces of legislation all mandate specific Forest Service management processes or activities and call on the agency to report to Congress on various matters of management and planning. Many scholars point to this statute-rich period as having a profound impact on the Forest Service by producing "a broadening of the mission regarding national forest management from multiple-use management of a few key resources to a policy of management and protection of a series of biologically diverse areas ..." (Tipple \& Wellmann, 1991, p. 423).

Two laws often credited with having a particularly significant impact on the Forest Service are NEPA and NFMA (Tipple \& Wellmann, 1991; Kennedy, 1988). The passage of NEPA in 1969 (83 Stat. 852, 42 U.S.C. 4321 et. seq.) served to modify the activities of all federal agencies by opening up their decisionmaking to public scrutiny and input, thereby altering irreversibly historical deference to and reliance on agency expertise (Wenner, 1982). NEPA imposed a complex decisionmaking process upon agencies, requiring an analysis of the environmental impacts of major federal actions, a consideration of alternatives, and efforts to reduce the proposed action's impacts. Opportunities for public comment were required at various steps along the process, which coincided with growing public interest in National Forest management (Ackerman, 1990). Citizen-initiated lawsuits were the consequence if the agency did not fulfill adequately the spirit of the law (Wenner, 1982). Because of the nature of the agency's actions, the greater part of Forest Service activities fall under the guidelines established by NEPA, including such activities as timber sales, grazing, and endangered species management plans (42 U.S.C. 161-230). Not surprisingly, given these procedural requirements, former USFS Chief Dale Robertson has noted that complying with NEPA's provisions is one of the most difficult tasks the agency faces (Robertson, 1992).

Passed in 1976, NFMA called upon the Forest Service and the administration to undertake long-term planning at the national, regional, and local levels (90 Stat. 2949, 16 U.S.C 472-576, 1600-1612). The RPA, as amended by NFMA, calls on the agency to submit to Congress national inventories of all forest lands every ten years and updated assessments every five years, and to report to Congress annually regarding all the ongoing activities on the National Forests. These Annual Reports have become a sort of report card on management activities and on the expenditure of funds appropriated for the Forest Service. The reports also update Congress on the activities specified either through legislation or appropriations language. In addition, NFMA 
establishes guidelines for timber sales, land purchases and exchanges, reforestation, and public participation in the drafting of forest management plans. NFMA was intended to give Congress greater oversight into the activities of the Forest Service and to hold the administration more accountable for long-range planning of agency activities (Parent, 1992; Dana \& Fairfax, 1980). Most importantly, given that citizens were beginning to turn to the courts to seek changes in National Forest management-in particular the controversial practice of clearcutting-Congress hoped through NFMA to "get the practice of forestry out of the courts" (Humphrey, 1976).

\section{Congressional Budget Allocations}

In addition to passing substantive forest management legislation via the authorizing committees, Congress also can have a major impact on the Forest Service via the budget process. Through the "power of the purse," Congress has ultimate power over what the Forest Service spends money on, and hence what the agency's priorities are (Congressional Quarterly, 1991b, p. 129; Sample, 1990). The Chief of the Forest Service noted at a joint oversight hearing before Congress that "ultimately the rate at which we are able to implement each [general management] plan-and the relative emphasis given to each component of the plan-reflects national priorities and constraints that are resolved as ... the Congress appropriates funds" (Robertson, 1989). Farnham recently undertook a detailed analysis of trends in both agency budget requests and congressional appropriations over 10 years. He found a trend of decreasing emphasis on traditional commodity programs such as timber and an increasing emphasis on non-commodity outputs such as fish and wildlife and recreation, although commodity program funding still far outweighed non-commodity allocations (Farnham, 1995; Farnham, Taylor, \& Callaway, 1995). While this trend also was found in the agency's budget requests, Farnham found it much more pronounced in final congressional appropriations, indicating that Congress likely had been the impetus for these shifts in emphasis (Farnham, 1995).

\section{Appropriations Bill Directives}

Despite the multitude of environmental bills enacted affecting the Forest Service in the 1960s and 1970s, NFMA marks the last major piece of legislation that comprehensively altered how the agency manages the National Forests. Since then, excluding annual budget allocations, the bulk of congressional measures that have influenced on-the-ground management of the National Forest System profoundly and directly have occurred as amendments to the annual appropriations bills (known as "riders") or in report language accompanying them (see, for example, Bolduan, 1990).

The annual appropriations bills are "must pass" items which, unlike most other legislation, are guaranteed to be enacted each year or the federal government would shut down for lack of funding (Congressional Quarterly, 1991b). Consequently, they provide easy vehicles for legislative amendments which otherwise would have to attain floor consideration via the more time-intensive authorizing committee process. The House rules technically forbid such "legislating on appropriations bills;" however, this rule is waived frequently (Congressional Quarterly, 1991b). The Senate, a much less structured body, does not have such rules.

As a result, in addition to mandating spending levels for the agency, the language contained in the annual appropriations bills often is very explicit in guiding the activities of the Forest Service (Congressional Quarterly, 1991a). The Conference Committee report language accompanying these spending measures often contains additional directives for agency operations (Congressional Quarterly, 1991a; Bolduan, 
1990). An examination of a sampling of this language is useful in illustrating the potential magnitude and range of congressional influence via appropriations directives.

One of the most frequent and far-reaching subjects for appropriations bill directives is judicial review of agency actions. Judicial review measures were attached to the annual appropriations bills for the agency six times between 1984 and 1992, and all of these measures served to prohibit or severely constrain legal challenges of various agency actions, usually timber sales. For example, in the fiscal year 1990 Interior appropriations bill, Congress exempted specific timber sales and NEPA actions in Oregon from review, and in Section 318 of the bill severely restricted appeals of plans or sales in all National Forests in Oregon and Washington (P.L. 101-121). In the words of Judge Schroeder, of the Ninth Circuit, Section 318 was "basically designed to provide a short-term supply of timber to Washington and Oregon lumber mills by limiting judicial review" (Seattle Audubon Society v. Evans, 952 F.2d 297, 9th Cir. 1991: 300). The Ninth Circuit found this provision an unconstitutional violation of the separation of powers doctrine, but the Supreme Court later overruled this decision (Seattle Audubon Society v. Robertson, 112 S. Ct. 1407, 1992).

The construction of timber roads is another frequent topic of appropriation bill directives, which have tended to vacillate between environmental and commodity concerns on this topic. In fiscal years 1982 and 1983, additional funds were appropriated for road construction in order to help the recession-plagued timber industry (P.L. 97-100; P.L. 97-394). However, concerns about the fragmentation, erosion, and sedimentation caused by road building, as well as the economics of this activity, inspired a successful campaign by environmental organizations in the mid1980s to reduce funding for roads in the National Forests, as reflected in the bills for fiscal years 1985-1987 (P.L. 98-473; P.L. 99-190; P.L. 99-591).

Endangered and threatened species also often are the target of appropriations bill directives, which sometimes have promoted their continued viability, and sometimes have not. For example, in addition to the aforementioned judicial review provisions that were inspired largely by concerns over the impacts of timber sale injunctions in its habitat, the northern spotted owl also was addressed by bills for fiscal years 1987, 1989, and 1990, which promoted research on the threatened bird and its habitat (P.L. 99-591; P.L. 100-446; P.L. 101-121). A similarly mixed message was directed towards another rare bird in fiscal year 1990, when Region 8 was told to continue to meet its timber targets while simultaneously protecting red-cockaded woodpecker colonies (P.L. 101-121). Other species have benefited from inclusion in appropriations bill language. For example, in 1991, the Forest Service was directed to participate in the Wolf Management Committee to develop a reintroduction plan for the endangered Rocky Mountain gray wolf (P.L. 101-512), and in 1992, the agency was directed to emphasize newly listed plants, fish, and the gray wolf as priorities for agency spending (P.L. 102-154). In contrast, the Forest Service was forbidden to spend unallocated money on the grizzly bear in both fiscal years 1985 and 1986 (P.L. 98-473; P.L. 99-190).

This sampling of report language shows the variety of Forest Service activities that Congress addresses and the extent to which Congress mandates specific agency actions. Some directives favor commodity production while others emphasize environmental protection, and many reflect the particular policy biases of powerful individuals in Congress, in particular, those serving on the Appropriations Committees. For example, many of the restrictive judicial review amendments were sponsored by Senate committee member Mark Hatfield, a Republican from Oregon, which is home to the spotted owl (Bolduan, 1990). All, however, are indicative of Congress's increasing tendency to become involved in the day-to-day activities of the Forest Service. 
Congressional oversight of federal agencies like the Forest Service is a desirable check and balance on the Executive Branch. In theory, as elected officials, members of Congress must be more accountable to the American people than are civil service agency personnel, and hence can help ensure that the agency manages the National Forests according to the public's priorities, whatever they may be. However, Congress's impact on the Forest Service is not always a positive one. In particular, the use of appropriations directives has come under attack from some who see it as resulting in inappropriate "micromanagement" that impedes positive agency change. Although the Appropriations Committees hold exhaustive series of hearings each year, these are focused on funding issues, and do not delve deeply into the process and substance of National Forest management, which is the domain of the authorizing committees. The result is that appropriations bill riders generally circumvent the hearing and debate process in the authorizing committees, under which other forest management initiatives are scrutinized and considered. Although hearings do not always provide for a comprehensive examination of a topic, they are useful as a public forum for addressing a subject and, at least in theory, provide for a balanced airing of the different sides of an issue by a spectrum of "experts." In addition to bypassing the normal legislative committee process, appropriations riders often address an issue only temporarily for one to two fiscal years, rather than providing a long term solution to it. Claims one critic of appropriation directives, "... riders become law without proper congressional scrutiny, provide only a piecemeal approach to forest resource use, and effectively leave decisions on the use of public forest land to the presumed expertise of these agencies" (Bolduan, 1990, p. 329).

A recent illustration of this sentiment is a salvage timber program that was attached as a rider to the fiscal year 1995 rescissions bill, H.R. 1158, ostensibly to address a forest health emergency affecting the National Forests. This 14-page amendment mandated that the Forest Service harvest a minimum of 6 billion additional board feet over a two-year period (almost double the fiscal year 1994 harvest from the National Forest System), suspended environmental law requirements and judicial review, and eliminated any administrative appeals - all without the benefit of a hearing in any of the authorizing committees that have jurisdiction over the Forest Service or the affected laws. Congressional opponents of the measure declared it "the largest congressionally sanctioned invasion in the history of our national forests by the timber industry" and complained that it "mocked" the House rules (Vento \& Yates, 1995) and was "an authorizing measure, not an appropriations measure" (National Journal, 1995).

\section{Direct Pressure on USFS Personnel}

In addition to official congressional statutes and budget allocations, congressional members also can affect the Forest Service's management of the National Forests by lobbying agency staff directly (Congressional Quarterly, 1991a; Durbin, 1990). Congressional scholars Davidson and Oleszek (1990, p. 271), report, "there is no measure of their usage, but nonstatutory controls may be the most common form of congressional oversight." Members of Congress, influenced by their constituency, district, and political leanings, act to move the Forest Service in the direction most beneficial, in their minds, to their constituents. Most commonly, congressional members are accused of pressuring Forest Service staff to "get the cut out" (Durbin, 1990; Save America's Forests, 1992). This practice is illustrated best by Senator Larry Craig's (R-ID) letter to Forest Service Chief Dale Robertson on May 23, 1991. Craig writes: 
Dear Dale, I am extremely concerned with the management situation that is being allowed to continue in Region 1.... To have gotten to the mid-year point of fiscal year 1991 and have only offered 16.2 percent of the assigned timber target illustrates to me a complete lack of management direction and execution.... The time has come to get down a month by month expectation and accomplishment for each Forest in Idaho and a summary of Region 1 timber accomplishments from the present through the end of the year. I wish to remain informed, on a monthly basis, of the progress that is made.... Dale, I am very disappointed with the Forest Service's accomplishment and accountability for timber outputs in Idaho and the Nation as a whole.... It is my hope that you will move to assure targets are met and line officers are held accountable for targets. As the ranking member on the Senate Subcommittee on Conservation and Forestry and a member of the Subcommittee on Public Lands, National Parks and Forests, I intend to take increased oversight of the operation of the Forest Service. It is my intent to keep a close watch on Forest Service management and to raise concerns on a regular basis (Craig, 1991).

Craig's letter was followed by the resignation of Region 1 Forester John Mumma in August 1991, the only wildlife biologist to rise to the ranks of Regional Forester. Mumma was given the option of a transfer to Washington, DC or early retirement (Association of Forest Service Employees for Environmental Ethics, 1991). The incident inspired an investigative hearing in the House Civil Service Subcommittee in September 1991, where Mumma testified:

I'm here with a heavy heart, a heart that's in shock at what's happening in the National Forests.... We have been legislatively required to sell a prescribed amount of timber but we have also been told that we have to comply with environmental and other laws. I have done everything I can to meet all of my targets. I have failed to reach the quotas only because to do so would have required me to violate federal law (Mumma, 1991).

A similar example was highlighted in the Pacific Northwest in the mid-1980s in an exchange between former Forest Service Chief Max Peterson and Representative Les AuCoin (D-OR) during a House Interior Appropriations Subcommittee hearing. AuCoin concluded his questioning of Peterson's reduction in timber sales by asserting that if Peterson did not increase the flow of timber out of Region 6, he should not expect to retain his position as Chief for any great length of time (United States House of Representatives, Interior Appropriations Subcommittee, 1986). Peterson left the agency within a year. Said Peterson later, "I think probably a half dozen times during my tenure someone put out the word it was time for me to leave. I don't think there's any question that some in the Pacific Northwest were glad to see me leave" (Durbin, 1990).

While anecdotal and not conclusively proven as the sole causes of Forest Service staff resignations, these exchanges illustrate the potential for individual congressional members to impact directly how the agency does its business. Many believe that such incidents are widespread. The Oregonian newspaper in Portland, Oregon reported: "Political pressure applied by AuCoin, Sen. Mark O. Hatfield, ROre., and other members of the Northwest delegation to keep the cut up was a fact of life for the Forest Service throughout the 1980s-until the northern spotted owl reared its feathered head" (Durbin, 1990).

Congress has the potential to impact federal agencies such as the Forest Service through a variety of means: congressional statutes, budget appropriations, 
appropriation bill directives, and direct lobbying. One way to examine Congress's potential role in instigating change within the Forest Service is to identify and quantify specific legislative branch actions related to the agency. This allows us to examine the trends in the frequency of these activities to see if any correlation exist with recently observed changes in the Forest Service.

\section{A Quantitative Analysis of Congressional Involvement}

Four types of congressional activities were examined quantitatively: (a) requests for Forest Service testimony; (b) the frequency of agency-related bills introduced; (c) the frequency of Forest Service-related amendments introduced; and (d) the amount of agency-related legislation that has been enacted. Data were collected from the Legis computer service database provided by Congress, using a search for all measures involving the "Forest Service" introduced during the 95th-102nd Congresses. It should be noted that all measures identified in this way do not necessarily impact the Forest Service significantly; for example, introduced bills range in impact on the agency from mandating the Forest Service's management of the northern spotted owl to encouraging all federal agencies to use recycled paper in their mailings. Nonetheless, since the goal was to show the relative change in these congressional activities and since the number of less important bills is likely to be relatively constant across the time period examined, the results are still useful in showing a trend in the amount of Forest Service-related legislation and its potential collective impact on the agency. Annual lists of agency testimony before Congress also were collected from the Forest Service's Washington Office.

\section{Forest Service Testimony Before Congress}

One of the primary functions of congressional committees is to conduct factfinding or investigative hearings at which "expert witnesses" are brought in to testify before committee members regarding a specific issue of concern and/or legislative proposals intended to address the issue (Congressional Quarterly, 1991a). Typically, whenever a congressional committee researches an issue or debates a specific measure affecting a federal agency, an agency staff person is requested to testify on behalf of the agency (Congressional Quarterly, 1988). The agency representative will prepare a written statement, give an oral presentation, and then answer committee members' questions. Testifying requires the agency to research the issue and develop a position on it, an activity often requiring considerable time investment (Congressional Quarterly, 1991a). Additionally, congressional hearings often are used by oversight committees to send a signal to the agency regarding a particular issue. Committee members often indicate their opinions either explicitly or implicitly through their questioning during the hearing; hence, they can provide direction and apply pressure to the agency without even passing legislation (Congressional Quarterly, 1991a).

As a result, one measurement of congressional involvement in Forest Service activities is how often the Forest Service is asked to testify before Congress, as this indicates the frequency with which committees are addressing agency activities. Table 1 illustrates that demand for testimony from the Forest Service more than tripled from 1969 to 1986, increasing from 32 statements in the 91st Congress (1969-1970) to 102 in the 98th Congress (1983-1984). Testimony frequency plummeted for unknown reasons in the 100th Congress (1987-1988) and then rose again, reaching 88 in 19891990, and a slightly lower 79 in the 102nd Congress. Unfortunately, Forest Service 
records are incomplete for both the 93rd and 99th Congresses. Nonetheless, the numbers indicate that overall congressional investigation of agency issues is increasing.

Table 1

Frequency of United States Forest Service (USFS) Testimony Before Congress, 1969-1992

$\begin{array}{cc}\text { Congress } & \text { Number of Times USFS Testified } \\ \text { 91st } & 32 \\ 92 \mathrm{nd} & 53 \\ \text { 93rd } & \text { no data } \\ 94 \text { th } & 68 \\ 95 \text { th } & 68 \\ 96 \text { th } & 70 \\ 97 \text { th } & 82 \\ 98 \text { th } & 102 \\ 99 \text { th } & \text { no data } \\ 100 \text { th } & 57 \\ 101 \text { th } & 88 \\ 102 \text { nd } & 79\end{array}$

\section{Forest Service Bills and Amendments}

A second measurement of congressional involvement in Forest Service activities is the number of bills and amendments introduced and enacted regarding the agency and its management activities. Such data provide an indication of the relative change in congressional activity over time. This trend, seen in Table 2, shows an increase in the number of bills introduced involving the Forest Service, from a low of 55 in the 95th Congress (1977-1978) to a high of 135 in the 102nd Congress (19911992).

\section{Table 2}

Frequency of Forest Service Legislation, 1977-1992

\begin{tabular}{cccc}
\hline $\begin{array}{c}\text { Congress } \\
\text { 95th }\end{array}$ & $\begin{array}{c}\text { \# of bills } \\
\text { introduced }\end{array}$ & $\begin{array}{c}\text { \# of floor } \\
\text { amendments offered }\end{array}$ & $\begin{array}{c}\text { \# of bills } \\
\text { enacted }\end{array}$ \\
96 th & 38 & 1 & 17 \\
97 th & 68 & 3 & 22 \\
98 th & 66 & 5 & 17 \\
99 th & 57 & 7 & 15 \\
100 th & 69 & 8 & 19 \\
101 th & 69 & 7 & 20 \\
102 nd & 96 & 16 & 28 \\
& 109 & & 26 \\
\hline
\end{tabular}

Similarly, an increased number of legislative amendments involving the Forest Service have been offered on the House and Senate floor (Table 2). With the exception of the 100th Congress, the number of such amendments, although small, has been 
increasing steadily from a low of 1 in the 95th Congress (1977-1978) to 16 in the 102nd Congress (1991-1992). Many of these measures are offered as amendments to the annual appropriations bills, and many involve controversial issues such as increased grazing fees on public lands, viability of below-cost timber sales, management of the northern spotted owl, and alteration of the judicial review process. The increased use of floor amendments to address Forest Service issues is likely to be linked to the difficulty of getting substantive legislation passed out of the authorizing committees. Many of the authorizing committees, such as Senate Energy and Natural Resources, and House Resources, have memberships that include many conservative western legislators who are protective of traditional commodity uses of federal lands, such as timber, mineral, and rangeland livestock production (Barry, 1991). As a result, many measures calling for greater emphasis on environmental protection and non-commodity uses of public lands have been stalled in these committees. Hence, individual legislators increasingly are bypassing the committees by offering floor amendments to appropriations and other bills. In turn, these efforts are met with amendments countering these viewpoints.

The frequency in use of floor amendments is likely to be affected somewhat by the characteristics of the particular Congress. For example, the Republican majority of the 104th Congress, which tends to be aligned more closely with traditional commodity production than with environmental protection (League of Conservation Voters, 1995), may find it easier to achieve its legislative goals for the National Forests in the authorizing committees than its Democratic predecessors. It should be kept in mind, however, that in any Congress the committee process represents a very time- and energy-intensive gauntlet (Congressional Quarterly, 1991a).

Only a small fraction of the more than 10,000 bills that members introduce each Congress ever are signed into law-less than 5\% (Congressional Quarterly, 1991b). This percentage was found to be somewhat higher for Forest Service-related legislative measures. As seen in Table 2, with the exception of the 95th Congress, enactment of agency measures has vacillated between $19 \%$ and $24 \%$ of bills introduced. In absolute terms, the number of laws passed affecting the Forest Service ranged between 15 and 22 annually from the 95 th to the 100th Congress, and then increased to highs of 28 and 27, in the 101st and 102nd Congresses, respectively.

\section{Summary and Recommendations}

The evidence provided in this study indicates that Congress's oversight of the Forest Service has been increasing. All of the quantitative measures examined-Forest Service testimony, bills introduced, floor amendments offered, and enacted laws affecting the agency-indicate that Congress has been increasing its scrutiny of and participation in the activities of the Forest Service. These results are corroborated by statements from the agency: Jerry Reese, Deputy Director of the USFS Legislative Affairs Office, maintains that the Office has increased its activities substantially in the past two decades (Reese, 1993). He notes that, in particular, activities related to compliance with NEPA and NFMA have created a great deal of additional work for the agency, as have the increasing number of bills introduced by Congress. While not by itself proof that these have resulted in change within the agency, at a minimum this increase in external pressure on the agency establishes Congress as a likely source of change.

Such a conclusion finds agreement among other scholars, many of whom believe that congressional activity, in particular the passage of legislation, has resulted 
in on-the-ground changes in how the Forest Service manages the National Forests. Kennedy (1988) maintains that the passage of environmental legislation, in particular NEPA, was useful in combating Forest Service "groupthink"- the tendency of agencies to become homogenous, rigid, and resistant to change-by mandating public involvement processes that subjected agency decisionmaking to public scrutiny and input. Similarly, Tipple and Wellmann (1991) point to natural resource legislation, among other factors, as contributing to opening up the agency and broadening its mission. Ackerman, a legal scholar, claims that NEPA has "accelerated and stimulated ... Forest Service change," noting that "the first twenty years of the National Environmental Policy Act of 1969 ... coincide with the most significant period of change that the United States Forest Service has undergone since it was established ..." (Ackerman, 1990). Through legislation and the hearings process, the Forest Service is forced to be answerable immediately to Congress. Many actions that the Forest Service might not have undertaken otherwise are directed by legislation, and the agency is obligated to carry out these measures. Increased public participation, the requirement for integrated management plans for each National Forest, and the movement towards more emphasis on non-commodity programs all have been mandated specifically by Congress through NFMA or NEPA. One could question credibly when, or even possibly whether, any of these actions would have taken place without the oversight role that Congress played.

These observations seem to indicate that Congress's ability to act statutorily to direct agency activities carries great power. However, congressional activity does not have to culminate in new statutes to influence agency action. According to Culhane's (1981) "rule of anticipated reactions," in its quest to avoid conflict, the Forest Service is receptive to external feedback, such as that from Congress and the public, and responds proactively by adjusting its decisions and actions to minimize the anticipated conflict before it can occur. Under this theory, the agency takes cues from Congress, such as members' questions and stated opinions at congressional hearings, letters from members of Congress, and the introduction of bills that address the agency's management of the National Forests, and reacts to address perceived shortcomings before it is forced legislatively to do so. Our anecdotal evidence of direct pressure on agency personnel by members of Congress, as well as the changes in annual budget requests noted by Farnham (1995), indicate that there likely is merit in Culhane's theory.

Ironically, Congress can serve as a primary obstacle to the Forest Service's implementation of the very statutes Congress enacted for it, by setting unrealistic timber harvest levels and by providing appropriations that are not in sync with the goals set through the RPA and NFMA planning processes that Congress itself mandated. As a result, the trend toward increasing congressional involvement in day-to-day agency operations of ten is viewed negatively by both the agency and outside interest groups. In Mohai's survey of USFS employees, "increasing political pressure on agency; outside interference" (which included both Congress and interest groups) was most frequently cited as the most important negative change in the Forest Service over the past 10 years (Mohai, Stillman, Jakes, \& Liggett, 1994). Similarly, in a recent survey of National Forest user groups involved in the Forest Service RPA planning process, non-consumptive and consumptive National Forest user groups and forestry schools all rated Congress as having a notably negative influence on change within the agency since the passage of NFMA in 1976 (Jones \& Mohai, 1995). However, in the same survey, NEPA and NFMA were rated by both the non-consumptive users and the forestry schools as having a definite positive influence on change within the Forest Service. This dichotomy between feelings about Congress and congressional 
legislation seems to indicate that perhaps it is not Congress's passage of additional authorizing legislative obligations that is viewed as having a negative impact, but other forms of congressional involvement, such as mandated cut levels, appropriations bill directives, or direct pressure on agency personnel, many of which conflict with this legislation.

Congress is not a static institution; change within Congress can also result in change within the Forest Service, as the House and Senate carry out their oversight responsibilities. Such a phenomenon is likely to be well-illustrated in the 104th Congress, where the Republican Party, which has been in the minority in the House for the past four decades, controls both chambers.

In conclusion, it appears that Congress has had significant influence on the agency in the past, has increased its involvement in agency activities, and is likely to continue this trend in the future. Congressional influence takes many forms and has both facilitated and impeded positive change within the agency. It is the authors' view that Congress best could assist the Forest Service's response to changing public values by providing clear, non-contradictory legislative guidance, setting budget levels that correspond to RPA and NFMA goals, minimizing the imposition of political pressure on agency personnel by individual members of Congress, and decreasing congressional use of appropriations bill "riders" for resolving controversial issues that deserve the investigation, debate, and public involvement provided better in the authorizing committee process.

Elise S. Jones is the natural resources legislative assistant for United States Representative Elizabeth Furse, who represents the First District of Oregon. Ms. Jones has a B.S. in natural resources from Cornell University and has worked on federal environmental policy issues in Washington, DC since 1989. At the time of the research, she was a graduate student at the School of Natural Resources and Environment of the University of Michigan, Ann Arbor, where she went on to receive an M.S. in natural resources policy.

William L. Callaway is a Washington representative for the National Parks and Conservation Association, where he monitors legislation and regulations affecting National Park Service activities. Previously, Mr. Callaway worked as a legislative assistant to Senator Harlan Mathews, and as a professional staff member to Senator Jim Sasser. In both positions his primary responsibility was to cover environmental and energy issues. Mr. Callaway holds an M.S. from the University of Michigan's School of Natural Resources and Environment and a B.A. from the University of Virginia. The research for this article was conducted while Mr. Callaway was a graduate student at the University of Michigan.

\section{References}

Ackerman, S. (1990). Observations on the transformation of the Forest Service: The effects of the National Environmental Policy Act on U. S. Forest Service decision making. Environmental Law, 20 (2), $703-734$.

Association of Forest Service Employees for Environmental Ethics (AFSEEE). (1991). Inner Voice, 3 (3), p. 1.

Barry, D. J. (1991). Amending the Endangered Species Act, the ransom of Red Chief, and other related topics. Environmental Law, 21 (3), 587-604.

Bolduan, L. M. (1990). The Hatfield riders: Eliminating the role of the courts in environmental decision making. Environmental Law, 20 (1), 329-385. 
Brown, G., \& Harris, C. C. (1992a). The U. S. Forest Service: Changing of the guard. Natural Resources Journal, 32, 449-466.

Brown, G., \& Harris, C. C. (1992b). The U. S. Forest Service: Toward the new resource management paradigm? Society \& Natural Resources, 5, 231-245.

Brown, G., \& Harris, C. C. (1993). The implications of workforce diversification in the U. S. Forest Service, Administration and Society, 25 (1), 85-113.

Congressional Quarterly. (1988). Congress $A$ to $Z, C Q$ 's ready reference encyclopedia. Washington, DC: Congressional Quarterly Press.

Congressional Quarterly. (1991a). Congressional Quarterly's guide to Congress (4th ed.). Washington, DC: Congressional Quarterly Press.

Congressional Quarterly. (1991b). How Congress works (2nd ed.). Washington, DC: Congressional Quarterly Press.

Craig, L. (1991, May 23). Letter to Forest Service Chief Dale Robertson, as excerpted in Inner Voice, 3 (3), p. 1.

Culhane, P. J. (1981). Public lands politics: Interest group influence on the Forest Service and the Bureau of Land Management. Baltimore, MD: Johns Hopkins University Press.

Dana, S. T., \& Fairfax, S. K. (1980). Forest and range policy. New York, NY: McGraw-Hill Book Company.

Davidson, R. H., \& Oleszek, W. J. (1990). Congress and its members (3rd ed.). Washington, DC: Congressional Quarterly Press.

Durbin, K. (1990, Oct. 15). Politics helped delay NW timber management plan. The Oregonian, pp. 7-11.

Famham, T. (1995). Forest Service budget requests and appropriations: What do analyses of trends reveal? Policy Studies Journal, 23 (2), 253-267.

Famham, T., \& Mohai, P. (1995). National forest timber management over the past decade: A change in emphasis for the Forest Service? Policy Studies Journal, 23 (2), 268-280.

Farnham, T., Taylor, C. P., \& Callaway, W. (1995). A shift in values: Non-commodity resource management and the Forest Service. Policy Studies Journal, 23 (2), 281-295.

Humphrey, H. H. (1976). 122 Congressional Record, p. 33835.

Jones, E. S., \& Taylor, C. P. (1995). Litigating agency change: The impact of the courts and administrative appeals process on the Forest Service. Policy Studies Journal, 23 (2), 310-336.

Jones, E. S., \& Mohai, P. (1995). Is the Forest Service keeping up with the times? Interest group and forestry school perceptions of post-NFMA change in the United States Forest Service. Policy Studies Journal, 23 (2), 351-371.

Kennedy, J. J. (1988). Legislative confrontation of groupthink in U. S. natural resource agencies. Environmental Conservation, 15 (2), 123-128.

Kennedy, J. J., Krannich, R. S., Quigley, T. M., \& Cramer, L. A. (1993). Employee perceptions of USDAForest Service values and the agency reward system. Paper presented at the 1993 Society of American Foresters' Annual Convention, Indianapolis, IN.

Kennedy, J. J. (1991). Integrating gender diverse and interdisciplinary professionals into traditional U. S. Department of Agriculture-Forest Service culture. Society and Natural Resources, 4, 165.

League of Conservation Voters. (1995, April). 100-day scorecard: National environmental scorecard for the House of Representatives. Washington, DC: Author.

McCarthy, C., Sabatier, P., \& Loomis, J. (1991). Attitudinal change in the Forest Service: 1960-1990. Paper presented at the 1991 Annual Meeting of the Western Political Science Association, Seattle, WA.

Mohai, P. (1995). The Forest Service since the National Forest Management Act: Assessing bureaucratic response to extemal and intemal forces for change. Policy Studies Journal, 23 (2), 247-252.

Mohai, P., \& Jakes, P. (in press). The Forest Service in the 1990s: Is it heading in the right direction?-A view from agency employees. Journal of Forestry.

Mohai, P., Stillman, P., Jakes, P., \& Liggett, C. (1994). Change in the USDA Forest Service: Are we heading in the right direction? General Technical Report NC-172. St. Paul, MN: United States Department of Agriculture, Forest Service, North Central Forest Experiment Station.

Mumma, J. (1991, Sept. 24). Statement presented at U. S. House Civil Service Subcommittee hearing (Directed reassignments of John Mumma and L. Lorraine Mintmyer, H. Hrg. Rpt. 102-27), 9-84.

National Journal. (1995, March 3). Abortion, timber issues surface in rescissions markup. Congress Daily/A.M., p. 3.

Parent, S. M. (1992). The National Forest Management Act: Out of the woods and back to the courts? Environmental Law, 22 (2), 699-702.

Reese, J. (1993, March 3). Personal communication with Jerry Reese, Depuly Director of Legislative Affairs, United States Department of Agriculture, Forest Service, Washington Office.

Robertson, D. (1989, Oct. 25). Statement presented at joint oversight hearing of the U.S. Senate Energy and Natural Resource Committee and Agriculture, Nutrition and Forestry Committee. (The national 
Policy Studies Journal, 23: 2

forest planning process as provided in the National Forest Management Act of 1976, S. Hrg. Rpt. 101-553), $24-49$.

Robertson, D. (1992, November 21). Personal communication with Dale Robertson, Chief, United States Department of Agriculture, Forest Service.

Sample, V. A. (1990). The Impact of the federal budget process on national forest planning. Westport, CT: Greenwood Publishing Co.

Save America's Forests. (1992). Regional 1 Forest Service coup: Political harassment. D.C. Update, 3 (1), 1-16.

Thomas, J. C., \& Mohai, P. (1995). Racial, gender, and professional diversification in the Forest Service from 1983 to 1992 . Policy Studies Journal, 23 (2), 296-309.

Tipple, T. J., \& Wellmann, J. D. (1991). Herbert Kaufman's forest ranger thirty years later: From simplicity and homogeneity to complexity and diversity. Public Administration Review, 51 (5), 421-428.

Twight, B. W. (1983). Organizational value and political power: The Forest Service versus the Olympic National Park. University Park and London: Pennsylvania State University Press.

United States House of Representatives, Interior Appropriations Subcommittee. (1986, April 7). Hearings on Department of the Interior and related agencies appropriations for 1987, (part 10), 11291432.

Vento, B., \& Yates, S. (1995, March 9). "Dear colleague" letter from Reps. Bruce Vento and Sid Yates to members of the United States House of Representatives.

Wenner, L. M.. (1982). The environmental decade in court. Bloomington: Indiana University Press.

West, T. (1992). Centennial mini-histories of the Forest Service. Washington, DC: United States Department of Agriculture, Forest Service. 
This document is a scanned copy of a printed document. No warranty is given about the accuracy of the copy. Users should refer to the original published version of the material. 